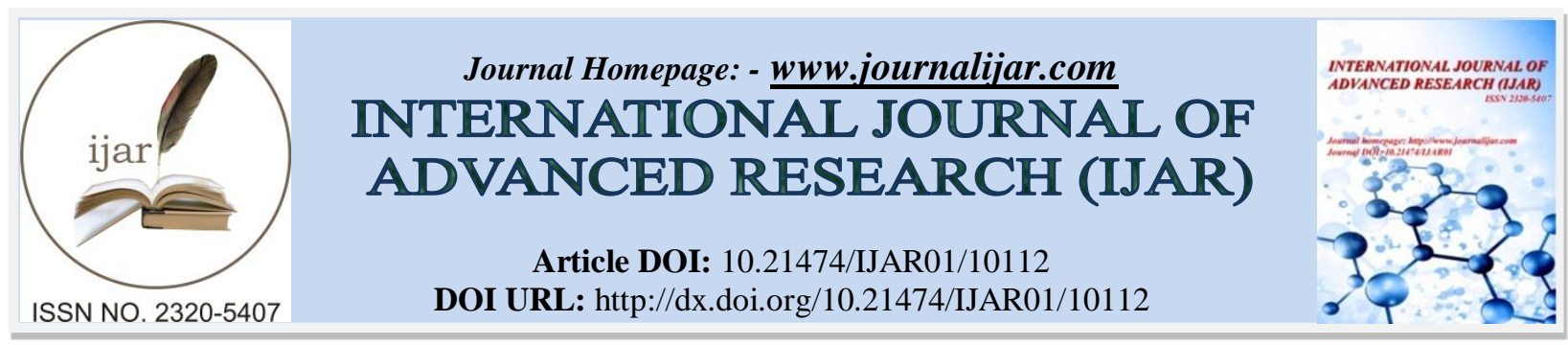

RESEARCH ARTICLE

\title{
PREVALENCE OF DEPRESSION AMONG PATIENTS WITH VITAMIN D DISTURBANCE AND RESPONSE TO TREATMENT AT ARMED HOSPITALS, TAIF 2018.
}

Dalal Siadi ALQurashi.

\section{Manuscript Info}

\section{Manuscript History}

Received: 14 September 2019

Final Accepted: 16 October 2019

Published: November 2019

\section{Abstract}

Objectives: To measure prevalence of depression among vitamin D deficiency and insufficiency patient attending armed hospital, Taif2018.

Methods: A cross-sectional study was implemented at Alhada Military Hospital, Taif city, Saudi Arabia included all adult patients attending family medicine clinic throughout the period Agust $1^{\text {st }}$-September 30, 2018 with either newly diagnosed vitamin D deficiency or insufficiency or on regular treatment for vitamin D disturbance. A prepared English interview checklist was used in collecting data from patient. DSM-V criteria were used for diagnosis major depression.

Results: The study included 213 patients. Their age ranged between 15 and 88 years, with a mean \pm SD of $47.6 \pm 15.8$ years. Majority of the participants had vitamin D insufficiency $(81.7 \%)$ while only $18.3 \%$ of them had vitamin D deficiency. More than one-third of the participants (36.6\%) were on current vitamin D treatment whereas $16.5 \%$ of them stopped treatment. The duration of vitamin D use was three months or more among $15.5 \%$ of the participants. Regarding the current dose, it was $5000 \mathrm{IU} /$ week among $29.1 \%$ of the patients. Major depression was diagnosed, based on DSM-V criteria in only two patients $(0.9 \%)$. Depression was present in 55.5\% of the participants, based on PHQ-9 questionnaire; it was mild among $36.6 \%$ and moderately severe or severe among $6.5 \%$ of them. Vitamin D disturbance was not significantly associated with depression.

Conclusions: The rate of depression is high among patients with vitamin $\mathrm{D}$ disturbance with no significant difference between patients with vitamin D deficiency and those with insufficiency.

Copy Right, IJAR, 2019,. All rights reserved.

\section{Introduction:-}

Vitamin D is one of a fat-soluble vitamin ${ }^{(1)}$. Most common source for vitamin D is the exposure of skin to the $\operatorname{sun}^{(1)}$. Synthesis and Chemistry of vitamin D are complex process. Sun exposure needed to convert 7 dehydrocholesterol to Vitamin D3 (cholecalciferol) by non-enzymatic role ${ }^{(1)}$. Then the formed vitamin D3 either from diet or sun, must chemically hydroxylated in liver by 25-hydroxylated, then 1-hydroxylated in the kidneys to the active form, 1,25-dihydroxycholecalciferol (calcitriol) ${ }^{(1)}$. Vitamin D deficiency occurs as a result of lack of exposure to sun or less dietary intake of vitamin rich food ${ }^{(2)}$. Moreover, if there are a problem with it is absorption or problem with hydroxylation in liver or kidney will affect its transformation to active form The active form of vitamin $\mathrm{D}, 1,25-(\mathrm{OH}) 2$ is an important molecule in calcium homeostasis and bone metabolism ${ }^{(2)}$. 
Vitamin D deficiency or insufficiency has been linked to many medical diseased such as autoimmune diseases ${ }^{(3,}$ 4). In 2005 First paper published studies the Distribution of vitamin D in human Brain(5). The vitamin D receptor (VDR) and the 1-alpha-hydroxylase enzyme that converts vitamin D to its active are expressed in the human brain $^{(5)}$

Depression is the most common worldwide psychological disorder. The association between vitamin D and mental health has been investigated in the past years. Multiple studies found low level of 25-hydroxyvitamin D $(25[\mathrm{OH}] \mathrm{D})$ in patients with depression or Alzheimer disease ${ }^{(6-8)}$.

Locally, Dr. Al Hariri conduct the study in Riyadh City concluded that level of depression among vitamin D Deficiency more than vitamin Insufficiency group but that result was not significant differences statistically ${ }^{(9)}$. Lacking of more local studies is needed to fill gap of knowledge.

\section{Method:-}

This research used an observational cross-sectional analytical design. The target populations were patients attending family medicine clinic at Alhada military hospital in the city of Taif, Saudi Arabia during the study period from 01.08.2018 to 30.09.2018. The optimal serum 25(OH)D concentration for skeletal health is are debatable in literature ${ }^{(10,11)}$. The cutoff values that was used in this research are the values that armed hospital adopt, which are vitamin D deficiency $\leq 10 \mathrm{ng} / \mathrm{mL}$ and vitamin $\mathrm{D}$ insufficiency between $10.1 \mathrm{ng} / \mathrm{mL}$ and 30 $\mathrm{ng} / \mathrm{mL}$

A prepared English interview checklist was used in collecting data from patient. Diagnostic and Statistical Manual of Mental Disorders, Fifth Edition (DSM-5) was used which, a valid tool for diagnosis major depression $^{(12)}$. The checklist had the following items: Patient information, Patient investigation, Patient medication: and Symptom of vitamin D.

\section{Results:-}

The study included 213 patients. Their age ranged between 15 and 88 years, with a mean \pm SD of $47.6 \pm 15.8$ years. Most of them were females (76.5\%), married (77.9\%) and unemployed or retired (78.4\%). Almost one-third of the participants $(34.7 \%)$ were illiterate whereas $20.2 \%$ were university or postgraduate.

Family history of depression was reported among $8.9 \%$ of the participants. History of chronic disease was reported by $59.6 \%$ of the participants. There chronic diseases were mainly diabetes mellitus (52.8\%), hypertension (37\%) and heart diseases (9.4\%). It is displayed from figure 1 that majority of the participants had vitamin D insufficiency $(81.7 \%$ ) while only $18.3 \%$ of them had vitamin D deficiency. Regarding Medication history among the participants, more than one-third of the participants $(36.6 \%)$ were on current vitamin D treatment whereas $16.5 \%$ of them stopped treatment. The duration of vitamin D use was three months or more among $15.5 \%$ of the participants. Regarding the current dose, it was 5000 IU/week among $29.1 \%$ of the patients. Antidepressants were not taken by all patients while medications for chronic diseases were reported by more than half of the participants $(57.7 \%)$. The commonest reported symptoms of vitamin D deficiency/insufficiency were bone aches (76.1\%), low back pain (63.4\%) and muscle aches $(61 \%)$.

Based on the responses of the participants to the DSM-V criteria for major depression. The commonest reported was energy loss or fatigue nearly every day $(25.8 \%)$, followed by sleep problems (insomnia or hypersomnia) nearly every day (18.8\%). Overall major depression was diagnosed, based on DSM-V criteria in only two patients $(0.9 \%)$. It is evident from figure 2, the depression was present in 55.5\% of the participants, based on PHQ-9 questionnaire; it was mild among $36.6 \%$ and moderately severe or severe among $6.5 \%$ of them.

As seen in table 2 and figure 3, depression overall was more reported among patients with vitamin D deficiency compared to those with vitamin D insufficiency (61.5\% versus $52.9 \%)$ and moreover, moderately severe/severe depression was more reported among patients with vitamin D deficiency compared to those with vitamin D insufficiency $(12.7 \%$ versus $5.2 \%$ ). However, these differences were not statistically significant. It is clear from table 3 that there was no statistically significant association between vitamin D medications, their duration and doses from one side and depression and its severity from the other side. Also, there was no statistically significant association between history of medications for chronic diseases and depression/its severity. 
Regarding Association between vitamin D deficiency/insufficiency and socio-demographic characteristics. Table 4 shows that there was a statistically significant association between the patient `s age and vitamin D status as $8.3 \%$ of patients aged over 60 years compared to $29.7 \%$ of those aged $\leq 30$ years had vitamin D deficiency, $p=0.003$. Also, there was a statistically significant association between educational level of the participants and their vitamin D status as $31.3 \%$ of patients with primary school education and $27.9 \%$ of those with university/postgraduate education compared to $8.1 \%$ of illiterate patients had vitamin D deficiency, $\mathrm{p}=0.022$. Patient $`$ gender, marital status and occupation were not significantly associated with vitamin D status.

\section{Discussion:-}

Up to date, several reviews investigated the possible association between vitamin D deficiency/insufficiency and depression with the majority of theses reviews reported that there is no sufficient evidence for such association ${ }^{(13}$,

In the present study, the rate of depression was high in general affecting more than half of patients with vitamin D disturbance; it was higher among patients with vitamin D deficiency compared to those with vitamin D insufficiency as hypothesized. However the difference was not significant. Conflicting results have been reported as some studies have demonstrated a strong relationship between vitamin D and depression ${ }^{(8,15-17)}$ whereas others

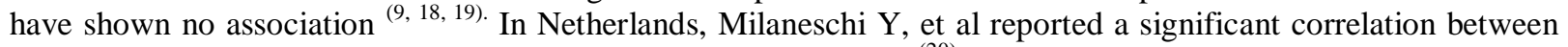
vitamin D level and depressive symptoms at a two-year follow up ${ }^{(20) .}$ In a study carried out in Jordan, depression was significantly higher among patients vitamin D deficiency even after controlling for confounders in multivariate logistic regression analysis ${ }^{(21)}$. In United Arab Emirates (UAE), Bani-Issa et al showed that the chance to had depression among Emirati members with vitamin D deficiency was significantly high. However, the study sample size was small and data collection method was uncontrolled ${ }^{(22)}$. In New Zealand, the prevalence of vitamin D deficiency was high among young adult and was significantly negatively associated with depression, assesses by CES-D scores after controlling for gender, age, BMI, and ethnicity ${ }^{(23)}$. Sotodehasl et al revealed in their review article that depression was associated with low levels of vitamin $\mathrm{D}^{(24)}$.

In the current study, majority of patients had vitamin D insufficiency (81.7\%) while only $18.3 \%$ of them had vitamin D deficiency. Vitamin D deficiency was more reported among younger patients in the present study, which is a surprising finding as it was expected that young people spent more time outdoor, which lead to their greater sun exposure and, therefore, higher levels of vitamin D compared to older people ${ }^{(25)}$. This finding may be explained by the recent westernization of the young people`s life in Saudi Arabia with lack of proper nutrition. This is contrary to what had been reported by others who found that older patients were more likely to be vitamin D deficient ${ }^{(26,27)}$.

In the present study and in agreement with another study carried out in United Arab of Emirates ${ }^{(22)}$, vitamin D deficiency was more reported among those of higher educational level compared to illiterates. Again, recent urbanization in Gulf area could be behind this finding.

In the current study, there was no statistically significant association between vitamin D medications, their duration and doses from one side and depression and its severity from the other side. This contradicts a study published in Australia, Parker GB et al confirmed the effect of vitamin D supplementation in improving parients with clinical depression. who are vitamin D inadequate ${ }^{(28)}$. However, it agrees with what had been reported in Poland by Gowda et al who showed no significant decrease in depressive symptoms after supplementation with vitamin $\mathrm{D}^{(29)}$. Also in Poland, Jozefowicz et al observed no association between low levels of 25(OH)D and response to treatment for depression ${ }^{(30)}$.

The most important limitation of the present study was its cross-sectional design which didn`t allow us to investigate the temporal relationship between vitamin D deficiency and depression. The second important limitation was its conduction in only two institutions in Taif which could impact the generalizability of results. Despite these two important limitations, the study is important in exploring this important issue in Taif community.

\section{Conclusion:-}

The rate of depression is high among patients with vitamin D disturbance with no significant difference between patients with vitamin D deficiency and those with insufficiency. However, rate of severe depression, based on DSM- 
$\mathrm{V}$ criteria is very low. No association is observed between vitamin D medications, their duration and doses from one side and depression and its severity from the other side.

\section{Advances in Knowledge}

1. The proof about the connection between vitamin D disturbance with depression still not understood.

2. Making baseline information about level of Depression among vitamin D deficiency and insufficiency patient.

3. To screen and diagnose depression among patients with vitamin D disturbance and promote appropriate intervention.

\section{Application to Patient Care}

1. The results of this study will give a general idea if there is a relation between vitamin D deficiency and insufficiency with depression.

2. The result of this study may help in developing awareness regarding screen those patient for depression.

Table 1:-Personal information of the participants $(n=213)$

\begin{tabular}{|l|l|l|}
\hline & Frequency & Percentage \\
\hline Age in years & \multicolumn{1}{|l|}{} \\
$\leq 30$ & 37 & 17.4 \\
$31-40$ & 32 & 15.0 \\
$41-50$ & 48 & 22.5 \\
$51-60$ & 60 & 28.2 \\
$>60$ & 36 & 16.9 \\
\hline Range & $15-88$ & \\
Mean \pm SD & $47.6 \pm 15.8$ & \\
\hline Gender & & 23.5 \\
Male & 50 & 76.5 \\
Female & 163 & \\
\hline Marital status & & 12.2 \\
Single & 26 & 77.9 \\
Married & 166 & 9.9 \\
Divorced/Widow & 21 & \\
\hline Occupation & & 78.4 \\
Unemployed/retired & 167 & 15.5 \\
Worker & 32 & 5.1 \\
Student & 13 & 34.7 \\
\hline Educational level & & 15.0 \\
Illiterate & 74 & 14.6 \\
Primary school & 32 & 15.5 \\
Intermediate school & 31 & 20.2 \\
Secondary school & 33 & \\
University/postgraduate study & 43 & \\
\hline
\end{tabular}




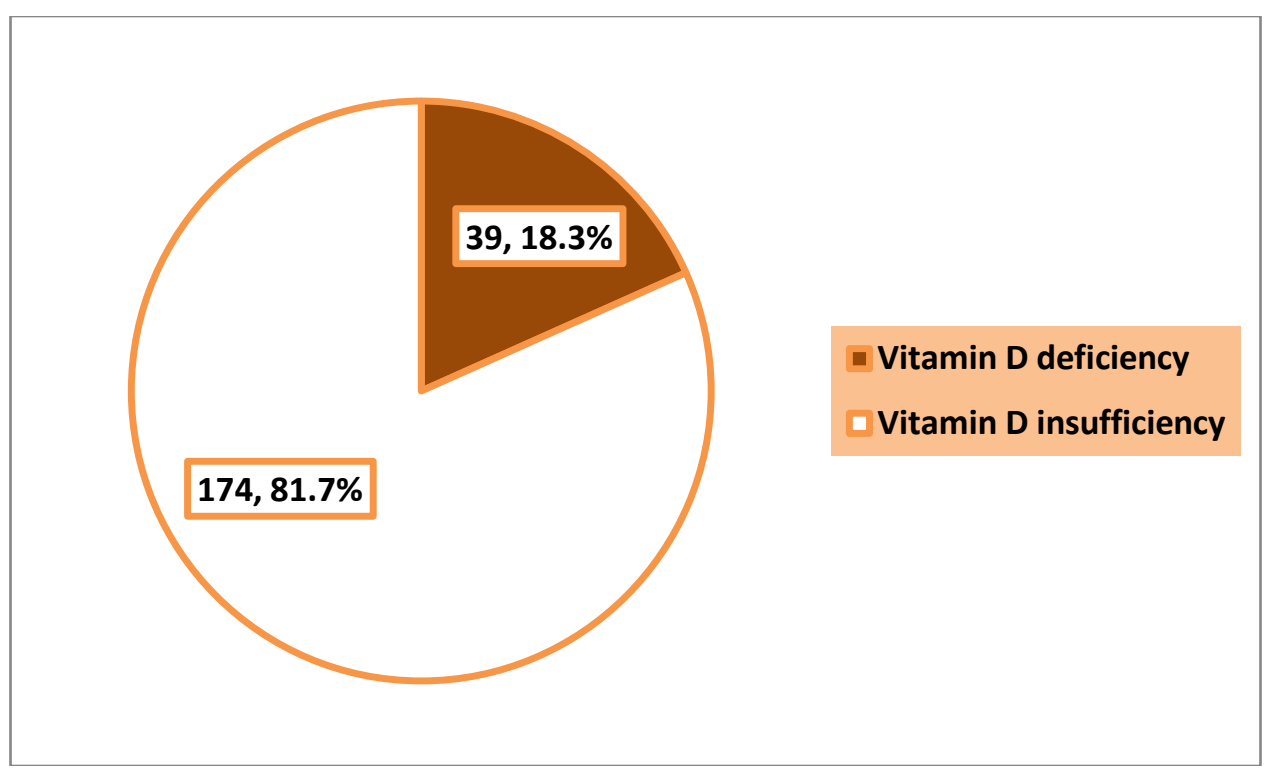

Figure 1:-Vitamin D level among the participants

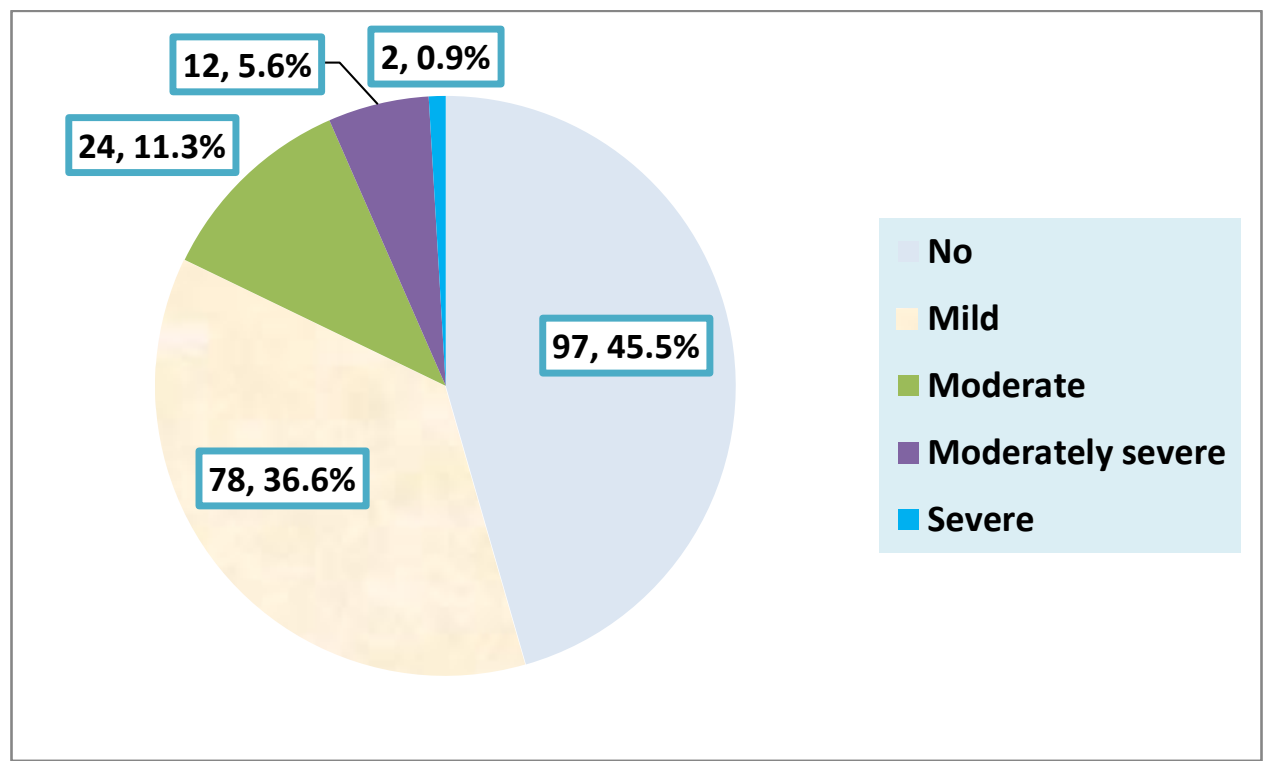

Figure 2:-Prevalence and severity of depression among the participants according to PHQ-9 questionnaire.

Table 2:-Association between vitamin D level and depression, based on PHQ-9 questionnaire

\begin{tabular}{|c|c|c|c|c|c|}
\hline \multirow[t]{3}{*}{ Vitamin D level } & \multicolumn{5}{|c|}{ Depression } \\
\hline & No & \multicolumn{4}{|l|}{ Yes } \\
\hline & $\begin{array}{l}\mathrm{N}=97 \\
\mathrm{~N}(\%)\end{array}$ & $\begin{array}{l}\text { Mild } \\
\mathrm{N}=78 \\
\mathrm{~N}(\%)\end{array}$ & $\begin{array}{l}\text { Moderate } \\
\mathrm{N}=24 \\
\mathrm{~N}(\%)\end{array}$ & $\begin{array}{l}\text { Moderately } \\
\text { sever/severe } \\
\mathrm{N}=14 \\
\mathrm{~N}(\%)\end{array}$ & $\begin{array}{l}\text { Total } \\
\mathrm{N}=116\end{array}$ \\
\hline Deficiency $(n=39$ & $15(38.5)$ & $15(38.5)$ & $4(10.3)$ & $5(12.7)$ & $25(61.5)$ \\
\hline $\begin{array}{l}\text { Insufficiency } \\
(\mathrm{n}=174)\end{array}$ & $82(47.1)$ & $63(36.2)$ & $20(11.5)$ & $9(5.2$ & $92(52.9)$ \\
\hline
\end{tabular}

Table 3:-Association between medication history and depression, based on PHQ-9 questionnaire among the participants 


\begin{tabular}{|c|c|c|c|c|c|c|c|}
\hline \multirow{3}{*}{ Vitamin D level } & \multicolumn{4}{|c|}{ Depression } & & \multirow{3}{*}{ p- } & \multirow[t]{3}{*}{ P-value2 } \\
\hline & \multirow{2}{*}{$\begin{array}{l}\text { No } \\
\mathrm{N}=97 \\
\mathrm{~N}(\%)\end{array}$} & \multicolumn{4}{|l|}{ Yes } & & \\
\hline & & $\begin{array}{l}\text { Mild } \\
\mathrm{N}=78 \\
\mathrm{~N}(\%)\end{array}$ & $\begin{array}{l}\text { Moderate } \\
\mathrm{N}=24 \\
\mathrm{~N}(\%)\end{array}$ & $\begin{array}{l}\text { Moderately } \\
\text { sever/severe } \\
\text { N=14 } \\
\mathrm{N}(\%)\end{array}$ & $\begin{array}{l}\text { Total } \\
\mathrm{N}=116\end{array}$ & & \\
\hline $\begin{array}{l}\text { On treatment of vitamin D } \\
\text { Not on treatment }(n=100)\end{array}$ & $49(49.0)$ & $33(33.0)$ & $11(11.0)$ & $7(7.0)$ & $51(51.0$ & & \\
\hline On current treatment $(n=78)$ & $28(35.9)$ & $35(44.9)$ & $9(11.5)$ & $6(7.7)$ & $50(64.1)$ & & \\
\hline Stop treatment $(\mathrm{n}=35)$ & $20(57.1)$ & $10(28.6)$ & $4(11.4)$ & $1(2.9)$ & $15(42.9)$ & 0.070 & 0.397 \\
\hline $\begin{array}{l}\text { Duration of vitamin D use } \\
\text { (months) } \\
\text { Not on medication }(n=135) \\
\leq 1(n=23) \\
2(n=22) \\
\geq 3(n=33)\end{array}$ & \begin{tabular}{|ll}
69 & $(51.1)$ \\
10 & $(43.5)$ \\
8 & $(36.4)$ \\
10 & $(30.3)$
\end{tabular} & $\begin{array}{l}43(31.9) \\
7(30.4) \\
10(45.5) \\
18(54.5)\end{array}$ & $\begin{array}{l}15(11.1) \\
2(8.7) \\
3(13.6) \\
4(12.1)\end{array}$ & $\begin{array}{ll}8 & (5.9) \\
4 & (17.4) \\
1 & (4.5) \\
1 & (3.0) \\
\end{array}$ & $\begin{array}{l}66(48.9) \\
13(56.5) \\
14(63.6) \\
23(69.7)\end{array}$ & 0.135 & 0.177 \\
\hline $\begin{array}{l}\text { Current dose of vitamin D used } \\
\text { Not on medication }(n=135) \\
50,000 \mathrm{IU} / \text { week }(\mathrm{n}=12) \\
5000 \mathrm{IU} / \text { week }(\mathrm{n}=62) \\
50,0000 \mathrm{IU} / \text { month }(\mathrm{n}=4)\end{array}$ & \begin{tabular}{|l}
$69(51.1)$ \\
$5(41.7)$ \\
$22(35.5)$ \\
$1(25.0)$ \\
\end{tabular} & $\begin{array}{l}43(31.9) \\
6(50.0) \\
26(41.9) \\
3(75.0) \\
\end{array}$ & $\begin{array}{l}15(11.1) \\
0(0.0) \\
9(15.4) \\
0(0.0) \\
\end{array}$ & $\begin{array}{ll}8 & (5.9) \\
1 & (8.3) \\
5 & (8.1) \\
0 & (0.0) \\
\end{array}$ & $\begin{array}{l}66(48.9) \\
7(58.3) \\
40(64.5) \\
3(75.0) \\
\end{array}$ & 0.174 & 0.417 \\
\hline $\begin{array}{l}\text { Medication for chronic diseases } \\
\text { Yes }(n=123) \\
\text { No }(n=90)\end{array}$ & $\begin{array}{l}43(47.8) \\
54(43.9)\end{array}$ & $\begin{array}{l}44(35.8) \\
34(37.8)\end{array}$ & $\begin{array}{l}15(12.2) \\
9(10.0)\end{array}$ & $\begin{array}{l}10(8.1) \\
4(4.4)\end{array}$ & $\begin{array}{l}80(52.2) \\
36(56.1)\end{array}$ & 0.575 & 0.677 \\
\hline
\end{tabular}

P-value 1: Depressed versus not depressed

P-value 2: Severity of depression

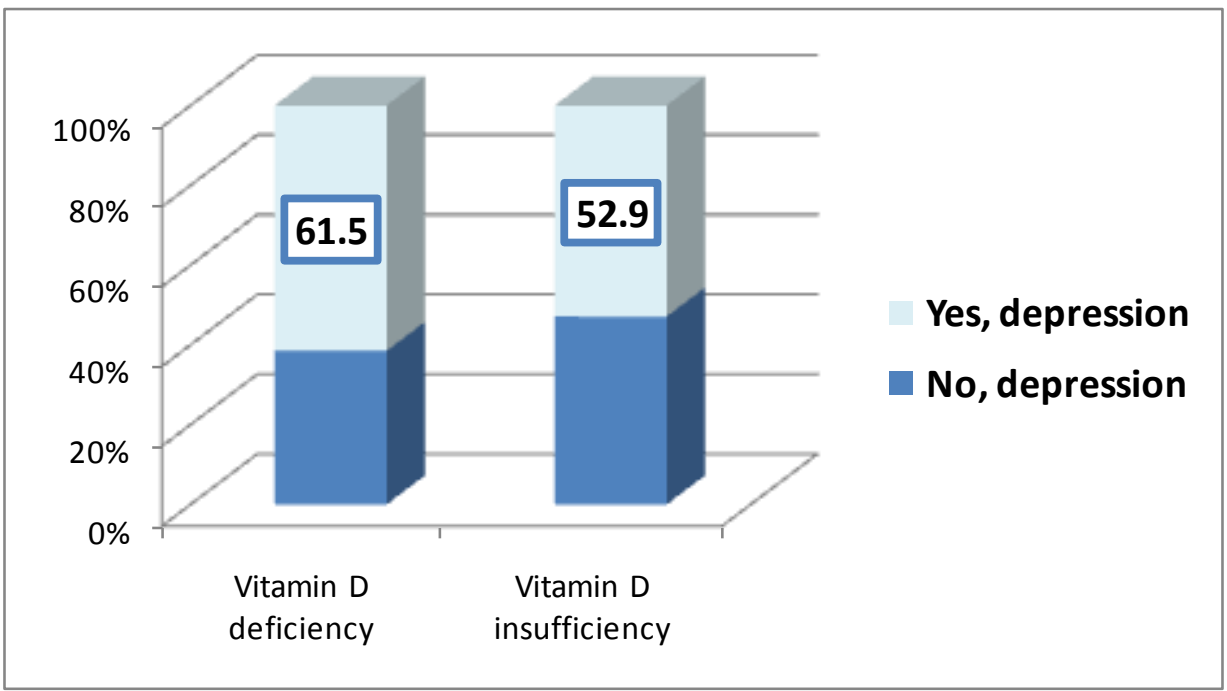

Figure 3:-Prevalence of depression among patients according to the vitamin D level status.

Table 4:-Association between vitamin D status and depression among the participants

\begin{tabular}{|c|c|c|c|}
\hline & \multicolumn{2}{|c|}{ Vitamin D status } & \multirow[t]{2}{*}{ p-value } \\
\hline & $\begin{array}{l}\text { Deficiency } \\
\mathbf{N}=39 \\
\mathbf{N}(\%)\end{array}$ & \begin{tabular}{|l|} 
Insufficiency \\
N=174 \\
$\mathrm{N}(\%)$
\end{tabular} & \\
\hline $\begin{array}{l}\text { Age in years } \\
\leq 30(n=37)\end{array}$ & $11(29.7)$ & $26(70.3)$ & \\
\hline
\end{tabular}




\begin{tabular}{|c|c|c|c|}
\hline $\begin{array}{l}31-40(\mathrm{n}=32) \\
41-50(\mathrm{n}=48) \\
51-60(\mathrm{n}=60) \\
>60(\mathrm{n}=36)\end{array}$ & $\begin{array}{l}9(28.1) \\
9(18.8) \\
7(11.7) \\
3(8.3)\end{array}$ & $\begin{array}{l}23(71.9) \\
39(81.3) \\
53(88.3) \\
33(91.7)\end{array}$ & 0.003* \\
\hline $\begin{array}{l}\text { Gender } \\
\text { Male }(\mathrm{n}=50) \\
\text { Female }(\mathrm{n}=163)\end{array}$ & $\begin{array}{l}7(14.0) \\
32(19.6)\end{array}$ & $\begin{array}{l}43(86.0) \\
131(80.4)\end{array}$ & $0.368^{*}$ \\
\hline $\begin{array}{l}\text { Marital status } \\
\text { Single }(n=26) \\
\text { Married }(n=166) \\
\text { Divorced/Widow }(n=21)\end{array}$ & $\begin{array}{l}4(15.4) \\
32(19.3) \\
3(14.3)\end{array}$ & $\begin{array}{l}22(84.6) \\
134(80.7) \\
18(85.7)\end{array}$ & $0.787 *$ \\
\hline $\begin{array}{l}\text { Occupation } \\
\text { Unemployed/retired }(\mathrm{n}=167) \\
\text { Worker }(\mathrm{n}=33) \\
\text { Student }(\mathrm{n}=13)\end{array}$ & $\begin{array}{l}28(16.8) \\
8(24.2) \\
3(23.1)\end{array}$ & $\begin{array}{l}139(83.2) \\
25(75.8) \\
10(76.9)\end{array}$ & $0.538^{*}$ \\
\hline $\begin{array}{l}\text { Educational level } \\
\text { Illiterate }(\mathrm{n}=74) \\
\text { Primary school }(\mathrm{n}=32) \\
\text { Intermediate school }(\mathrm{n}=31) \\
\text { Secondary school }(\mathrm{n}=33) \\
\text { University/postgraduate study }(\mathrm{n}=43)\end{array}$ & $\begin{array}{l}6(8.1) \\
10(31.3) \\
5(16.1) \\
6(18.2) \\
12(27.9)\end{array}$ & $\begin{array}{l}68(91.9) \\
22(68.8) \\
26(83.9) \\
27(81.8) \\
31(72.1)\end{array}$ & $0.022 *$ \\
\hline
\end{tabular}

* Chi-square test

\section{References:-}

1. Sassan Pazirandeh M, David L Burns, MD. Overview of vitamin D. In: Kathleen J Motil M, PhD,Marc K Drezner, MD, editor. UpToDate. UpToDate, Jean E Mulder, MD. (Accessed on November 28,2017.): UpToDate.

2. Marc K Drezner M. Causes of vitamin D deficiency and resistance. In: Clifford J Rosen M, editor. UpToDate. UpToDate, Jean E Mulder, MD. ( Accessed on October 23,2017): UpToDate.

3. Cantorna MT, Zhu Y, Froicu M, Wittke A. Vitamin D status, 1, 25-dihydroxyvitamin D3, and the immune system. The American journal of clinical nutrition. 2004;80(6):1717S-20S.

4. Holick MF. Vitamin D: important for prevention of osteoporosis, cardiovascular heart disease, type 1 diabetes, autoimmune diseases, and some cancers. SOUTHERN MEDICAL JOURNAL-BIRMINGHAM ALABAMA-. 2005;98(10):1024.

5. Eyles DW, Smith S, Kinobe R, Hewison M, McGrath JJ. Distribution of the vitamin D receptor and $1 \alpha-$ hydroxylase in human brain. Journal of chemical neuroanatomy. 2005;29(1):21-30.

6. Lee DM, Tajar A, O’Neill TW, O’Connor DB, Bartfai G, Boonen S, et al. Lower vitamin D levels are associated with depression among community-dwelling European men. Journal of psychopharmacology. 2011;25(10):1320-8.

7. Balion C, Griffith LE, Strifler L, Henderson M, Patterson C, Heckman G, et al. Vitamin D, cognition, and dementia A systematic review and meta-analysis. Neurology. 2012;79(13):1397-405.

8. Anglin RE, Samaan Z, Walter SD, McDonald SD. Vitamin D deficiency and depression in adults: systematic review and meta-analysis. The British journal of psychiatry. 2013;202(2):100-7.

9. Al Hariri A. Depression and Vitamin D Deficiency/Insufficiency among Saudis: The Relationships and Differences. Vitamins \& Minerals. 2016;5:143.

10. Dawson-Hughes B, Harris SS, Krall EA, Dallal GE. Effect of calcium and vitamin D supplementation on bone density in men and women 65 years of age or older. New England Journal of Medicine. 1997;337(10):670-6.

11. Trivedi DP, Doll R, Khaw KT. Effect of four monthly oral vitamin D3 (cholecalciferol) supplementation on fractures and mortality in men and women living in the community: randomised double blind controlled trial. Bmj. 2003;326(7387):469.

12. American Psychiatric Association. Diagnostic and statistical manual of mental disorders,. 5th, (DSM-5). ed. Washington, DC: American Psychiatric Publishing; ; 2013.

13. Spedding S. Vitamin D and depression: a systematic review and meta-analysis comparing studies with and without biological flaws. Nutrients. 2014;6(4):1501-18. 
14. Giordano N, Goracci A, Fagiolini A. Depression and Vitamin D deficiency: Causality, assessment, and clinical practice implications. Neuropsychiatry. 2017;7(5):606-14.

15. de Oliveira C, Hirani V, Biddulph JP. Associations between vitamin D levels and depressive symptoms in later life: evidence from the English Longitudinal Study of Ageing (ELSA). The Journals of Gerontology: Series A. 2017.

16. Pu D, Luo J, Wang Y, Ju B, Lv X, Fan P, et al. Prevalence of depression and anxiety in rheumatoid arthritis patients and their associations with serum vitamin D level. Clinical rheumatology. 2018;37(1):179-84.

17. Humble MB. Vitamin D, light and mental health. Journal of Photochemistry and Photobiology B: Biology. 2010;101(2):142-9.

18. Kwon SI, Son JS, Kim YO, Chae CH, Kim JH, Kim CW, et al. Association between serum vitamin D and depressive symptoms among female workers in the manufacturing industry. Annals of occupational and environmental medicine. 2015;27(1):28.

19. Jovanova O, Aarts N, Noordam R, Carola-Zillikens M, Hofman A, Tiemeier H. Vitamin D serum levels are cross-sectionally but not prospectively associated with late-life depression. Acta Psychiatrica Scandinavica. 2017;135(3):185-94.

20. Milaneschi Y, Hoogendijk W, Lips P, Heijboer A, Schoevers R, Van Hemert A, et al. The association between low vitamin D and depressive disorders. Molecular psychiatry. 2014;19(4):444.

21. Jaddou H, Batieha A, Khader Y, Kanaan S, El-Khateeb M, Ajlouni K. Depression is associated with low levels of 25-hydroxyvitamin D among Jordanian adults: results from a national population survey. European archives of psychiatry and clinical neuroscience. 2012;262(4):321-7.

22. Bani-Issa W, Eldeirawi K, Harfil S, Fakhry R. Vitamin D deficiency and its determinants in adults: A sample from community-based settings in the United Arab Emirates. International journal of endocrinology. 2017;2017.

23. Polak MA, Houghton LA, Reeder AI, Harper MJ, Conner TS. Serum 25-hydroxyvitamin D concentrations and depressive symptoms among young adult men and women. Nutrients. 2014;6(11):4720-30.

24. Sotodehasl N, Malek F, Tamadon MR. Vitamin D Deficiency and Depression: A Short Review Article. Middle East Journal of Rehabilitation and Health. 2015;2(3).

25. Batieha A, Khader Y, Jaddou H, Hyassat D, Batieha Z, Khateeb M, et al. Vitamin D status in Jordan: dress style and gender discrepancies. Annals of Nutrition and Metabolism. 2011;58(1):10-8.

26. Gaikwad M, Vanlint S, Moseley GL, Mittinty MN, Stocks N. Factors associated with vitamin d testing, deficiency, intake, and supplementation in patients with chronic pain. Journal of dietary supplements. 2018;15(5):636-48.

27. Lagunova Z, Porojnicu AC, Lindberg F, Hexeberg S, Moan J. The dependency of vitamin D status on body mass index, gender, age and season. Anticancer research. 2009;29(9):3713-20.

28. Parker GB, Brotchie H, Graham RK. Vitamin D and depression. Journal of affective disorders. 2017;208:56-61.

29. Gowda U, Mutowo MP, Smith BJ, Wluka AE, Renzaho AM. Vitamin D supplementation to reduce depression in adults: meta-analysis of randomized controlled trials. Nutrition. 2015;31(3):421-9.

30. Józefowicz O, Rabe-Jablonska J, Wozniacka A, Strzelecki D. Analysis of vitamin D status in major depression. Journal of Psychiatric Practice®. 2014;20(5):329-37. 